\title{
Clinical implications and histological correlation of atypical glandular cells found in cervicovaginal smears
}

\author{
Importância clínica e correlação histológica das células glandulares \\ atípicas detectadas no exame colpocitológico
}

Beliza Loos ${ }^{1}$; Karina Munhoz de Paula Alves Coelho ${ }^{1}$; Paulo Henrique Condeixa de França $a^{2}$; Giuliano Stefanello Bublitz ${ }^{3}$ Hercílio Fronza Júnior ${ }^{4}$

\begin{abstract}
Introduction: Atypical glandular cells (AGC) are carriers of insufficient nuclear abnormalities for the diagnosis of adenocarcinoma, but exceed the criteria for classification as reactive glandular cells. This is an uncommon diagnosis, which may be associated with neoplastic lesions. Objective: To evaluate the clinical significance of primary cytological diagnosis of AGC through correlation with results of subsequent cyto-histologic examination. Materials and methods: 10 years retrospective study based on cervical cytologic results indicating AGC, classified as "possibly non-neoplastic" or "cannot exclude high-grade intraepithelial lesion". It was performed cyto-histopathological correlation in cases that were submitted to subsequent histopathological examination up to two years after cervical cytology analysis. Results: AGC were reported in $380(0.06 \%)$ exams, providing 160 cases with subsequent biopsy. 85 (53.1\%) of these, presented benign changes and 75 (46.9\%) neoplastic lesions. From 114 "possibly non-neoplastic" cytological results, 71 (62.3\%) had benign histological changes, and 43 (37.7\%) neoplastic lesions, corresponding to a negative predictive value (NPV) of 62.3\%. In contrast, among the 46 AGC "cannot exclude high-grade intraepithelial lesion" results, 14 (30.4\%) presented benign changes and 32 (69.6\%) neoplastic lesions (positive predictive value $[\mathrm{PPV}]=69.6 \%$ ). Discussion: The high rate of cancer associated with the diagnosis of AGC reassures the importance of recognizing these atypical cells in pap smears. The classification of "possibly non-neoplastic" and "cannot exclude high-grade intraepithelial lesion" may suggest the origin of cytological changes. Conclusion: Our results reinforce the importance of adequate follow-up of patients with AGC diagnosis on cervical cytology.
\end{abstract}

Key words: atypical glandular cells; Pap smears; cancer.

\section{INTRODUCTION}

The diagnostic category of "atypical glandular cells of undetermined significance" (AGUS) was initially proposed by the Bethesda System in 1988, and has been periodically reviewed with an effort at properly qualify these findings. In 2001, the term AGUS was abandoned, and was replaced by "atypical glandular cells" (AGC) to avoid similarity with the acronym ASCUS ("atypical squamous cells of undetermined significance") ${ }^{(7,14)}$. These glandular atypia are defined as cells with insufficient nuclear changes for diagnosis of adenocarcinoma, but that exceeds the criteria for classification as reactive glandular cells or reparative process ${ }^{(2,11)}$.
It is an uncommon diagnosis, reported ten times less than the atypical squamous cells in cytological examinations ${ }^{(2)}$. Although the incidence of this cytological change may vary from one diagnostic service to another, theirvalues ranges from 0.1 to $2.1 \%(9,15,17)$.In Brazil, according to the Ministry of Health data for 2009, it was diagnosed 0.13\% AGC among all satisfactory examinations performed, and $4.6 \%$ considering only the abnormal results ${ }^{(10)}$. We also know that AGC diagnosis tends to be more frequent in patients older than 40 years of age, representing up to $71.4 \%$ of cases $^{(11)}$.

Despite the low prevalence, this diagnostic finding is relevant, since it can be related to both benign and neoplastic reactive processes. Among benign or reactive changes are included

First submission on 22/07/13; last submission on 06/02/14; accepted for publication on 02/05/14; published on 20/08/14

1. Physician; resident in Pathology at Hospital Municipal São José, Joinville-SC.

2. PhD in Microbiology; professor of the Post-graduation Program in Health and Environment-Universidade da Região de Joinville (UNIVILLE).

3. Pathologist; MsC in Health and Environmen-UNIVILLE.

4. Pathologist; specialist in Pathology-Sociedade Brasileira de Patologia and in Cytopathology-Sociedade Brasileira de Citopatologia; technical director at Centro de Diagnósticos

Anátomo-patológicos (CEDAP), Joinville-SC. 
endocervical and endometrial polyps, tubal metaplasia, cervical endometriosis, microglandular hyperplasia, genital tract inflammatory changes, and direct sampling of the lower uterine segment cells. On the other hand, it may also represent/correspond to squamous and glandular cervical lesions (malignant and pre-malignant), endometrial hyperplasia, invasive endometrial adenocarcinoma, and extra-uterine tumor (tubal, ovarian, and bowel), among others ${ }^{(2,3,11,12)}$.

ACG are divided in two groups, according to their estimated significance: "possibly non-neoplastic" or "cannot exclude highgrade intraepithelial lesion", as the Nomenclatura Brasileira para Laudos de Colpocitologia (Brazilian Nomenclature for Cervical Cytology Reporting). The recommended approach, indeed, is the same, implying recommendation of immediate investigation through colposcopy with histological evaluation ${ }^{(5,13)}$.

\section{OBJECTIVES}

To correlate AGC diagnosed cases in cervical cytology with the corresponding results of histological analysis, and to evaluate the significance of stratification in "cannot exclude high-grade intraepithelial lesion" and "possibly non-neoplastic" through the positive predictive (PPV) and negative predictive (NPV) estimating values, respectively.

\section{MATERIALS AND METHODS}

It was performed cohort, longitudinal and retrospective study, based on analysis of results from Pap smears and histopathological examinations carried out at Centro de Diagnósticos Anátomo-patológicos (CEDAP), in Joinville-SC, during January 2001-December 2010. The average age of patients in studied sample is $44.1( \pm 12.7)$ years. The reports analyzed included only conventional cytology, stained by Papanicolaou method, from patients from the city of Joinville and neighborhoods, from private and public health department, with AGC results classified as "possibly non-neoplastic" or "cannot exclude high-grade intraepithelial lesion". These are described according to criteria defined by Nomenclatura Brasileira para Laudos de Colpocitologia ${ }^{(1)}$. CEDAP laboratory follows the standard established by the College of American Pathologists and the Organização Nacional de Acreditação (National Accreditation Agency), because it is accredited by both institutions.

It was held cyto-histologic correlation in cases showing subsequent histopathological results up to two years after AGC Pap smears diagnosis. Patients who did not presented such results were excluded from the study.

The results of the histopathological examinations were divided in two groups, and were classified as benign or malignant processes. The proportions were evaluated by calculating PPV and NPV.

The study was approved by the Research Ethics Committee of the Universidade da Região de Joinville, in Joinville-SC ( Case No. 168712 , in 12/12/2012).

\section{RESULTS}

During the period considered, it was performed 627722 Pap smears, $380(0.06 \%)$ AGC diagnoses were registered. In the first and second five-year periods, it were identified 163 (0.05\%) and 217 (0.07\%) AGC diagnoses, in 299699 and 328023 Pap smears, respectively. Only $160(44.9 \%)$ patients with first diagnosis of AGC $(n=356)$ performed follow-up with biopsy(ies) within the next two years, and there was observed $114(71.3 \%)$ results classified as "possibly non-neoplastic" and $46(28.7 \%)$ as "cannot exclude high-grade intraepithelial lesion". On correlative histological evaluation, however, it was found 85 (53.1\%) cases of benign changes, and 75 (46.9\%) neoplastic changes (Table)

Among the 114 cases that had been classified as "possibly non-neoplastic" lesions in cytological evaluation, $62.3 \%(n=71)$ showed benign changes in biopsy, and $37.7 \%(n=43)$ showed

TABLE - PPV and NPV for AGC diagnosis "possibly non-neoplastic" and "cannot dismiss high-grade intraepithelial lesion", according to cyto-histopathological correlation

\begin{tabular}{cccccc}
\hline AGC & Neoplastics biopsies & Benign biopsies & Total & PPV (\%) & NPV (\%) \\
\hline Cannot exclude high-grade intraepithelial lesion & 32 & 14 & 46 & 69.6 & - \\
Possibly non-neoplastic & 43 & 71 & 114 & - & 62.3 \\
Total & 75 & 85 & 160 & - & - \\
\hline
\end{tabular}

PPV: positive predictive value; NPV: negative predictive value; AGC: atypical glandular cells. 
neoplastic changes in fact. On the other hand, among the 46 results reported as "cannot exclude high-grade intraepithelial lesion," 30.4\% $(n=14)$ showed benign changes, and 69.6\% ( $n=$ 32), neoplastic changes (Table).

Then, we analyzed PPV for the diagnostic category "cannot exclude high-grade intraepithelial lesion" in Pap smears, resulting in $69.6 \%$, while NPV for the category "possibly non-neoplastic" resulted in $62.3 \%$ (Table). When only considering patients aged 40 years or older $(n=103)$, the observed PPV and NPV reached $58.1 \%$ and $66.7 \%$, respectively.

\section{DISCUSSION}

Although uncommon in the set of cytologic screening diagnoses of cervical cancer, AGC has increased in recent decades ${ }^{(9)}$. Patients with AGC diagnosis may have cervical intraepithelial neoplasia (CIN) II and III (9\% to $54 \%$ of cases), adenocarcinoma in situ (up to 8\%) and invasive adenocarcinoma (1\% to $9 \%$ ) in histopathological examination" ${ }^{(1)}$ AGC classification in "possibly nonneoplastic" and "cannot exclude high-grade intraepithelial lesion" may suggest the origin of cytological change. However, the histological correlation has not been reported and the recommended conduct is subsequent colposcopy, with no difference between the two groups ${ }^{(1)}$.

In our casuistry, the prevalence of diagnoses compatible with AGC was only $0.06 \%$ among all cervical cytological examinations performed during the period considered, which is below the national rate $(0.13 \%)$ indicated by the Brazil's Ministry of Health. However, other reports of Brazilian studies showed similar or lower values, as the one performed at Santa Casa de São Paulo, in which 91210 cytology were evaluated over 3 years and 4 months, and 159 cases of AGC $(0.002 \%)$ were found ${ }^{(2)}$.

Mood et al., in a retrospective study conducted in Iran between April 1998 and March 2001, found that 52.4\% of patients with AGC had squamous or glandular neoplastic or preneoplastic lesions in subsequent histological examination ${ }^{(11)}$. In 2005, a study performed in Canada from 456 diagnoses of AGC found, in histological follow-up, 40 patients with cervical adenocarcinoma in situ, and 48 endometrial cancer, numbering $19.2 \%$ of malignant lesions in histological examination ${ }^{(4)}$. Valdini et al., in an American study, found 17.4\% dysplastic and cancer lesions in the follow-up biopsies after AGC initial diagnosis ${ }^{(16)}$. In this study, the prevalence of malignant lesions $(46.9 \%)$ in histological follow-up is similar to previously published results by other authors.

One limitation of this study comes from the short period of patients follow-up, which was only two years, from cytological diagnosis to the result of histological examination; once it is known that the period of evolution of an initial cervical lesion into the invasive form, and therefore, malignant lesion, may be up to 20 years ${ }^{(6)}$. Another important point is the significant number of patients excluded from the study (55.1\%), due to the unavailability of follow-up data after AGC diagnosis. It would be required and recommended further investigation to find out the reasons why these patients were not properly monitored. A likely scenario correspond to the situation in which physicians, when faced with AGC cytologic result, choose to repeat the examination instead of continuing the conduct recommended flowchart for women with such diagnosis. Another hypothesis would be the possibility that some patients may have been subjected to colposcopy, but showed no apparent lesion, and therefore, were not subjected to histopathological examination. In addition, patients may have performed subsequent follow-up in other services in the region, or even in other cities, becoming not possible to monitor the outcome of these cases.

Challenges in AGC diagnosis are well documented, mainly due to high inter-observer variability, low specificity, and low $\mathrm{PPV}^{(8,14)}$, such as the one found in this study $(69.6 \%)$, which is in agreement with the low prevalence of the observed phenomenon. Additionally, the fact that NPV (66.7\%) found is higher than PPV (58.1\%), in the examination of patients aged 40 years or more, shows that the sensitivity of cytology AGC diagnosis in Pap smears is higher than the specificity of corresponding age group. The high rates of neoplasia associated with AGC diagnosis, as described in the literature ${ }^{(4,11,16)}$, as observed in this study (46.9\%; 75/160), reassure the importance of training professionals who work in cytopathology for proper recognition of these changes and indication of clinical follow-up performing colposcopy and histological evaluation.

\section{CONCLUSION}

The results reinforce the importance of improving diagnosis and appropriate histological follow-up of patients with AGC in colpocitology, since it was verified its association with malignancy. 


\section{RESUMO}

Introdução: Células glandulares atípicas (CGA) são portadoras de alterações nucleares insuficientes para o diagnóstico de adenocarcinoma, mas excedem os critérios para classificação como células glandulares reacionais. Trata-se de um diagnóstico incomum, porém pode relacionar-se com lesões neoplásicas. Objetivo: Avaliar o significado clínico do diagnóstico citológico primário indicando CGApor meio da correlação com os resultados de exames histológicos subsequentes. Materiais e métodos: Estudo retrospectivo de 10 anos com base em resultados colpocitológicos indicando CGA, classificados como "possivelmente não neoplásicas" ou "não se pode afastar lesão intraepitelial de alto grau". Realizou-se a correlação cito-histopatológica nos casos que foram submetidos ao exame bistopatológico até dois anos após a análise colpocitológica. Resultados: CGA foram relatadas em 380 (0,06\%) exames, dispondo-se de 160 casos com biópsia subsequente. Destes, 85 (53,1\%) apresentavam alteracõoes benignas e 75 (46,9\%), lesões neoplásicas. Dos 114 resultados citológicos "possivelmente não neoplásicas", 71 (62,3\%) apresentavam alterações histológicas benignas e 43 (37,7\%), neoplásicas, correspondendo a um valor preditivo negativo (VPN) equivalente a 62,3\%. Contrariamente, entre os 46 resultados de CGA "não se pode afastar lesão intraepitelial de alto grau", 14 (30,4\%) apresentavam alterações benignas e 32 (69,6\%), neoplásicas (valor preditivo positivo [VPP] = 69,6\%). Discussão: As altas taxas de neoplasias associadas ao diagnóstico de CGA reafirmam a importância do reconhecimento dessas atipias. A classificação em "possivelmente não neoplásicas" e "não se pode afastar lesão intraepitelial de alto grau" pode sugerir a origem das alterações citológicas. Conclusão: Nossos resultados reforçam a importância do seguimento adequado das pacientes com diagnóstico de CGA no exame colpocitológico.

Unitermos: células glandulares atípicas; colpocitologia; câncer.

\section{REFERENCES}

1. BRASIL, Ministério da Saúde. Secretaria de Atenção à Saúde. Instituto Nacional do Câncer. Coordenação de Prevenção e Vigilância. Nomenclatura brasileira para laudos cervicais e condutas preconizadas: recomendações para profissionais de saúde. 2. ed. Rio de Janeiro: INCA, 2006. Available at: <http://bvsms.saude.gov.br/bvs/publicacoes/ Nomenclaturas_2_1705.pdf>. Accessed on: Fev. 2, 2013.

2. CAMPANER, A. B. et al. Células glandulares atípicas em esfregaços cervicovaginais: significância e aspectos atuais. J Bras Patol Med Lab, v. 43, n. 1, p. 37-43, 2007.

3. CHAN, C. W.; CHEUNG, K. B. Clinical significance and management of cervical atypical glandular cells of undetermined significance. Hong Kong Med J, v. 9, n. 5, p. 346-51, 2003.

4. DANIEL, A. et al. Histologic and clinical significance of atypical glandular cells on pap smears. Int J Gynaecol Obstet, v. 91, n. 3, p. 23842, 2005 .

5. DIAZ-MONTEZ, T. P. et al. Clinical utility of atypical glandular cells (AGC) classification: cytohistologic comparison and relationship to HPV results. Gynecol Oncol, v. 104, n. 2, p. 366-71, 2007.

6. HALBE, H. W. Tratado de ginecologia. 2. ed. São Paulo: Roca, 1993; v. 2. 7. LAI, C. R. et al. Clinical significance of atypical glandular cells by the 2001 Bethesda System in cytohistologic correlation. Acta Cytol, v. 52, n. 5, 2008 .
8. MARIANI, R. et al. Can we improve the positive predictive value of atypical glandular cells not otherwise specified? Diagn Cytopathol, 2013.

9. MARQUES, J. P. et al. Atypical glandular cells and cervical cancer: a systematic review. Rev Assoc Med Bras, v. 57, n. 2, p. 229-33, 2011.

10. MINISTÉRIO DA SAÚDE/INCA. Diretrizes Brasileiras para 0 Rastreamento do câncer do colo do útero. 2011.

11. MOOD, N. I. et al. Cytohistologic study of atypical glandular cells detected in cervical smears during cervical screening tests in Iran. Int J Gynecol Cancer, v. 16, n. 1, p. 257-61, 2006.

12. SCHNATZ, P. F. et al. Clinical significance of atypical glandular cells on cervical cytology. Obstet Gynecol, v. 107, n. 3, p. 701-8, 2006.

13. SHARPLESS, K. E. et al. Dysplasia associated with atypical glandular cells on cervical cytology. Obstet Gynecol, v. 105, n. 3, p. 494-500, 2005.

14. SOLOMON, D; NAYAR, R. Sistema bethesda para citopatologia cervicovaginal. Rio de Janeiro: Revinter, 2004.

15. SOOFER, S. B.; SIDAWY, M. K. Atypical glandular cells of undetermined significance: clinically significant lesions and means of patient followup. Cancer, v. 90, n. 4, p. 207-14, 2000.

16. VALDINI, A. et al. Incidence and evaluation of an AGUS Papanicolaou smear in primary care. JAm Board Fam Pract, v. 14, n. 3, p. 172-7, 2001.

17. ZHAO, C. et al. Histologic follow-up results in 662 patients with Pap test findings of atypical glandular cells: results from a large academic women hospital laboratory employing sensitive screening methods. Gynecol Oncol, v. 114, n. 3, 2009.

\section{MAILING ADDRESS}

Karina Munhoz de Paula Alves Coelho

Rua Mário Lobo, 61, 6º andar, Edifício Terraço Center; CEP: 89201-330; Joinville-SC, Brazil; e-mail: karinamunhoz@hotmail.com 